\title{
BIOLOGICAL VALUE OF RED BEETS IN RELATION TO NITROGEN FERTILIZATION
}

\author{
Anna SZURA, Iwona KOWALSKA, Włodzimierz SADY \\ Department of Soil Cultivation and Fertilization of Horticultural Plants \\ Agricultural University in Krakow \\ $29^{\text {th }}$ Listopada 54 Str., 31-425 Kraków, Poland
}

Received: June 28, 2007, Accepted: November 14, 2007

\section{Summary}

Effects of nitrogen fertilizer and fertilization method on biological value of red beet roots (cv. Boro $\mathrm{F}_{1}$ ) were studied in pot experiments conducted in 2005 and 2006 years. Pre-sowing nitrogen fertilizers were either UAN (ureaammonium nitrate solution) or ENTEC 26 (nitrogen fertilizer containing nitrification inhibitor). For both fertilizers the following methods of application were studied: pre-sowing superficially $90 \mathrm{~kg} \mathrm{~N} \cdot \mathrm{ha}^{-1}(\mathrm{~S}-100 \%)$, pre-sowing superficially $67.5 \mathrm{~kg} \mathrm{~N} \cdot \mathrm{ha}^{-1}$ with additional foliar nitrogen application during vegetation $(\mathrm{S}-75 \%+\mathrm{F})$, pre-sowing localized $67.5 \mathrm{~kg} \mathrm{~N} \cdot \mathrm{ha}^{-1}$ (L-75\%) and pre-sowing localized $67.5 \mathrm{~kg} \mathrm{~N} \cdot \mathrm{ha}^{-1}$ with additional foliar nitrogen application during vegetation $(\mathrm{L}-75 \%+\mathrm{F})$. In harvested roots the contents of dry matter, sugars, phenols, $\mathrm{NO}_{3}{ }^{-}, \mathrm{NH}_{4}{ }^{+}, \mathrm{N}$-protein and $\mathrm{P}, \mathrm{K}, \mathrm{Mg}$ and $\mathrm{Ca}$ were determined.

Type of nitrogen fertilizer had no effect on dry matter, $\mathrm{NH}_{4}{ }^{+}, \mathrm{N}$-protein, sugars, phenols, $\mathrm{Ca}$ and $\mathrm{Mg}$ contents in both years and on $\mathrm{K}$ in 2005 year. ENTEC 26 reduced nitrates content, particularly in 2005 year. The effect of fertilization method was not univocal, particularly for $\mathrm{NO}_{3}{ }^{-}$content. In 2005 the lowest $\mathrm{NO}_{3}{ }^{-}$content was found in treatment $\mathrm{S}-100 \%$ roots, whereas in 2006 in L$75 \%$. In both years the highest sugars content was observed in L-75\% roots, and the lowest N-protein in S-100\% roots. In both years the method of fertilization had no effect on dry matter, $\mathrm{NH}_{4}{ }^{+}$and phenols contents. The effect of fertilization method of on mineral composition was apparent only in 2006 year.

It can be concluded that by using the fertilizer with inhibitor of nitrification the biological value of red beets assessed by nitrate content can be improved. The effect of method of fertilizer application on the biological value of red beets is not univocal and may depend on the year of cultivation.

key words: nitrogen fertilization, method of application, chemical composition, nitrates 


\section{INTRODUCTION}

Red beets belong to the group of plants which easily cumulate nitrates in their vegetative organs (Rożek 2000). High nitrate content in plants is harmful for human, since the products of nitrate transformation cause methaemoglobinaemia, lower blood pressure and may destroy vitamins A, B and carotenoids (Smoczyński \& Skibniewska 1996).

Nitrate content in plants, including red beets, depend among others on bioavailability of soil $\mathrm{NO}_{3}{ }^{-}$. Fertilization with reduced forms of nitrogen $\left(\mathrm{NH}_{4}{ }^{+}\right.$ or urea), combined with application of methods reducing nitrification process may allow for decreasing nitrate uptake by plants. A decrease in nitrification intensity may be also obtained among others by means of localized nitrogen fertilization (CULTAN method) or introduction of nitrification inhibitors to the soil (Sommer 1991, Chaves et al. 2006). Decreased nitrate content in plants was also observed when amide-N was applied by foliar application (Rożek et al. 2000). Little is known on the use of above means in red beet cultivation. The aim of this study was to investigate the effects of nitrogen fertilizer form and fertilization method, including superficial, localized or foliar on concentrations of nitrates in red beet roots as well as on the content of sugars, phenols and macroelements, which are compounds responsible for red beet biological value.

\section{MATERIAL AND METHODS}

The pot experiment was conducted in the open area in 2005 and 2006 years. Red beet of Boro $F_{1}$ cultivar was cultivated in $50 \times 40 \times 25 \mathrm{~cm}$ boxes filled with silt loam containing $2.7 \%$ of organic matter. The soil $\mathrm{pH}_{\mathrm{H} 20}$ was 6.8 . In both years seeds were sown on May 10 and the vegetation period lasted 90 and 75 days in the first and second year, respectively. The seeds were sown in two rows with $20 \times 8 \mathrm{~cm}$ spacing. Based on the soil chemical analysis, potassium and phosphorus fertilizers were applied at the level of 250 and $70 \mathrm{mg} \cdot \mathrm{dm}^{-3}$, respectively. Soil concentrations of $\mathrm{Mg}$ and Ca were 140 and $1245 \mathrm{mg} \cdot \mathrm{dm}^{-3}$, respectively and did not need supplementation.

Nitrogen was applied before seed sowing using either UAN (urea-

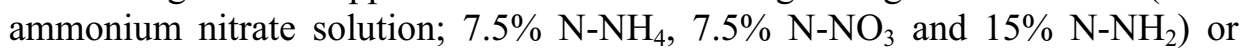

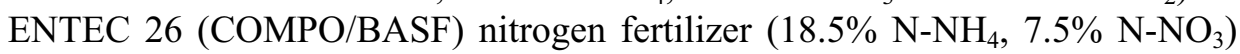
containing nitrification inhibitor DMPP. For both fertilizers the following methods of application were studied: pre-sowing superficially $90 \mathrm{~kg} \mathrm{~N} \cdot \mathrm{ha}^{-1}$ (S-100\%), pre-sowing superficially $67.5 \mathrm{~kg} \mathrm{~N} \cdot \mathrm{ha}^{-1}$ with additional foliar nitrogen application during vegetation $(\mathrm{S}-75 \%+\mathrm{F})$, pre-sowing localized $67.5 \mathrm{~kg}$ $\mathrm{N} \cdot \mathrm{ha}^{-1}$ (L-75\%) and pre-sowing localized $67.5 \mathrm{~kg} \mathrm{~N} \cdot \mathrm{ha}^{-1}$ with additional foliar nitrogen application during vegetation $(\mathrm{L}-75 \%+\mathrm{F})$. There were four replications for each treatment. Fertilizers applied superficially were handy covered by soil. Localized fertilization was applied by injection of fertilizer between seed rows to the soil depth of $5 \mathrm{~cm}$. Foliar nutrition was applied three times during plant vegetation. The first foliar nutrition with $2 \%$ urea solution was conducted at the 
stage of intensive plant growth. Then, the plants were foliary fed twice at twoweek intervals with first nutrition with Supervit R (1\%) and then again with urea $(2 \%)$. The plants were handy watered during cultivation to maintain the constant soil humidity. The distribution of mean daily air temperatures in both years are presented in Fig. 1.

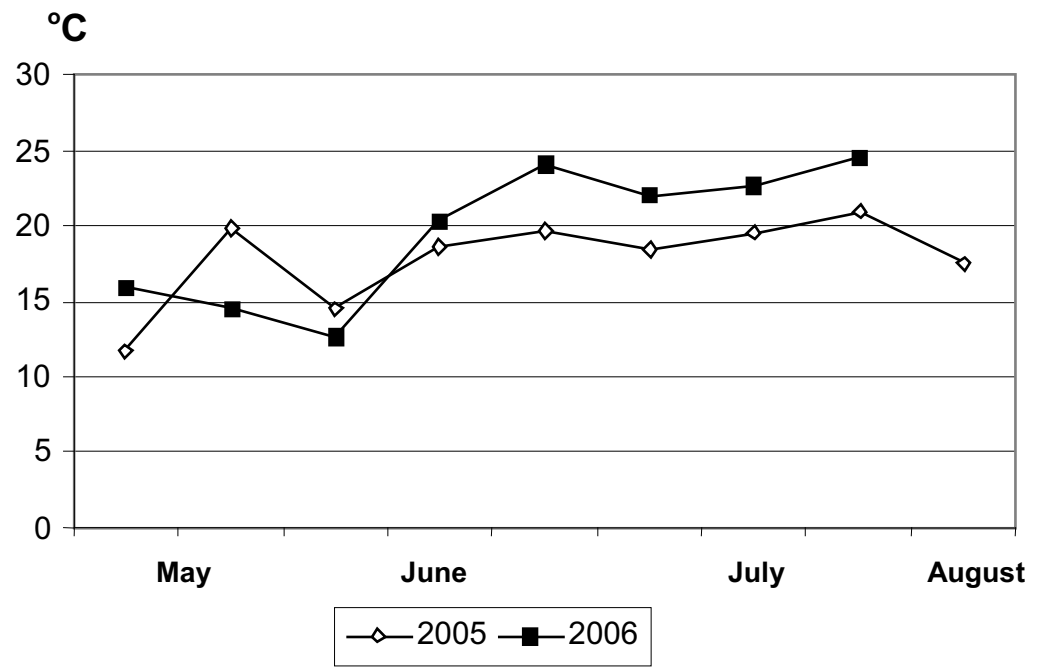

Fig. 1. Mean air temperatures during experiment (year 2005 and 2006)

Representative samples of beet roots were analyzed chemically at harvest maturity. The contents of $\mathrm{NO}_{3}{ }^{-}$and $\mathrm{NH}_{4}{ }^{+}$were determined using ion selective electrode following the plant material extraction with $0.02 \mathrm{M} \mathrm{Al}_{2}\left(\mathrm{SO}_{4}\right)_{3}$. Total contents of $\mathrm{P}, \mathrm{K}, \mathrm{Mg}$ and $\mathrm{Ca}$ were assessed after mineralization in the mixture of $\mathrm{HNO}_{3}, \mathrm{HClO}_{4}, \mathrm{H}_{2} \mathrm{SO}_{4}$ (6:2:0.25) (Jędrzejczak 1991). Then, phosphorus was determined calorimetrically and other elements using AAS method. Dry matter was determined by oven drying, N-protein using Kjeldahl method, the sum of phenols by reaction with Foli reagent (Peri \& Pompei 1971), soluble sugars by anthrone method (Yemm \& Wills 1954).

The results were subjected to the two-way analysis of variance (Statistica 7) with type of fertilizer and method of fertilization being the experimental factors. The differences between means were analyzed by LSD Fischer test and the significance of differences was declared at $\mathrm{P}=0.05$.

\section{RESULTS}

Type of nitrogen fertilizer had no effect on the contents of dry matter, $\mathrm{NH}_{4}{ }^{+}, \mathrm{N}$-protein, sugars, phenols, $\mathrm{Ca}$ and $\mathrm{Mg}$ in both years (Tables 1-4) and $\mathrm{K}$ in 2005 year (Table 2). On the other hand, ENTEC 26 reduced nitrates content in both years, although differences between fertilizers were statistically significant only in 2005, when beet roots fertilized with ENTEC 26 contained twice less nitrates than those fertilized with UAN. Moreover, fertilization with ENTEC 26 increased P content in 2005 and decreased K and P contents in 2006. 
Table 1. Effects of nitrogen fertilizer and fertilization method on the contents of nitrogen, sugars and phenols in red beet roots in 2005

\begin{tabular}{|c|c|c|c|c|c|c|}
\hline Fertilizers & $\begin{array}{c}\text { Fertilization } \\
\text { method }\end{array}$ & $\begin{array}{c}\mathrm{NH}_{4}^{+} \\
\mathrm{mg} \cdot \mathrm{kg}^{-1} \text { f.m. }\end{array}$ & $\begin{array}{c}\mathrm{NO}_{3}^{-} \\
\mathrm{mg} \cdot \mathrm{kg}^{-1} \text { f.m. }\end{array}$ & $\begin{array}{l}\text { N protein } \\
\% \text { d.m. }\end{array}$ & $\begin{array}{l}\text { Sugars } \\
\% \text { f.m. }\end{array}$ & $\begin{array}{c}\text { Phenols } \\
\mathrm{mg} \cdot 100 \mathrm{~g}^{-1} \text { f.m. }\end{array}$ \\
\hline \multirow[t]{4}{*}{ UAN } & S-100\% & 492 & 65 & 1.48 & 7.49 & 114 \\
\hline & $\mathrm{S}-75 \%+\mathrm{F}$ & 491 & 176 & 1.77 & 6.90 & 115 \\
\hline & $\mathrm{L}-75 \%$ & 472 & 131 & 1.60 & 8.42 & 116 \\
\hline & $\mathrm{L}-75 \%+\mathrm{F}$ & 479 & 145 & 1.71 & 8.00 & 111 \\
\hline \multirow[t]{4}{*}{ ENTEC 26} & S-100\% & 490 & 60 & 1.53 & 8.10 & 114 \\
\hline & $\mathrm{S}-75 \%+\mathrm{F}$ & 465 & 44 & 1.52 & 7.57 & 122 \\
\hline & $\mathrm{L}-75 \%$ & 467 & 66 & 1.56 & 7.48 & 122 \\
\hline & $\mathrm{L}-75 \%+\mathrm{F}$ & 478 & 85 & 1.78 & 6.64 & 123 \\
\hline \multirow{3}{*}{$\begin{array}{l}\text { Means for: } \\
\text { fertilizers }\end{array}$} & & & & & & \\
\hline & UAN & 483 & 129 & 1.64 & 7.70 & 114 \\
\hline & ENTEC 26 & 475 & 64 & 1.60 & 7.45 & 120 \\
\hline \multirow{4}{*}{$\begin{array}{r}\text { fertilization } \\
\text { method }\end{array}$} & S-100\% & 491 & 62 & 1.51 & 7.80 & 114 \\
\hline & $\mathrm{S}-75 \%+\mathrm{F}$ & 478 & 110 & 1.65 & 7.23 & 119 \\
\hline & L-75\% & 470 & 98 & 1.58 & 7.95 & 119 \\
\hline & $\mathrm{L}-75 \%+\mathrm{F}$ & 478 & 115 & 1.74 & 7.32 & 117 \\
\hline \multirow{4}{*}{\multicolumn{2}{|c|}{$\begin{array}{l}\mathrm{LSD}_{0.05} \text { for: } \\
\text { fertilizer } \\
\text { fertilization method } \\
\text { interaction }\end{array}$}} & & & & & \\
\hline & & n.s. & 20.0 & n.s. & n.s. & n.s. \\
\hline & & n.s. & 28.3 & 0.160 & 0.358 & n.s. \\
\hline & & n.s. & 40.0 & n.s. & 0.506 & n.s. \\
\hline
\end{tabular}

Note: S-100\% - pre-sowing superficially $90 \mathrm{~kg} \mathrm{~N} \cdot \mathrm{ha}^{-1}$; S-75\%+F - pre-sowing superficially $67.5 \mathrm{~kg} \mathrm{~N} \cdot \mathrm{ha}^{-1}$ with additional foliar nitrogen application during vegetation; L-75\% - pre-sowing localized $67.5 \mathrm{~kg} \mathrm{~N} \cdot \mathrm{ha}^{-1}$; L-75\%+F - pre-sowing localized $67.5 \mathrm{~kg} \mathrm{~N} \cdot \mathrm{ha}^{-1}$ with additional foliar nitrogen application during vegetation; n.s. - non-significant differences

In both years the method of fertilization, irrespective of the type of fertilizer, had no effect on dry matter, $\mathrm{NH}_{4}{ }^{+}$and phenols contents. For other compounds, the effect of fertilization method was not so univocal, particularly for $\mathrm{NO}_{3}{ }^{-}$. In 2005 year the lowest $\mathrm{NO}_{3}{ }^{-}$content was found in beets fertilized superficially (S-100\%), whereas in 2006 year in L-75\% beets. Moreover, in this year the highest $\mathrm{NO}_{3}{ }^{-}$content was found in $\mathrm{S}-100 \%$ beets. The highest $\mathrm{N}$-protein contents were found in $\mathrm{L}-75 \%+\mathrm{F}$ and $\mathrm{L}-75 \%$ beets, in the year 2005 and 2006 respectively, whereas the lowest in S-100\% roots, in both years. Irrespective of a year of cultivation, the highest sugars content was observed in L-75\% roots. The effect of the fertilization method on mineral composition of roots was apparent only in 2006 year. The lowest contents of $\mathrm{K}, \mathrm{Mg}$ and $\mathrm{Ca}$ were shown in L-75\% beets. Differences among other treatments were not significant. 
Table 2. Effects of nitrogen fertilizer and fertilization method on the contents of dry matter, phosphorus, potassium, magnesium and calcium in red beet roots in 2005

\begin{tabular}{|c|c|c|c|c|c|c|}
\hline \multirow{2}{*}{ Fertilizer } & \multirow{2}{*}{$\begin{array}{l}\text { Fertilization } \\
\text { method }\end{array}$} & \multirow{2}{*}{$\begin{array}{c}\text { Dry matter } \\
\%\end{array}$} & $\mathrm{P}$ & $\mathrm{K}$ & $\mathrm{Mg}$ & $\mathrm{Ca}$ \\
\hline & & & \multicolumn{4}{|c|}{ \%d.m. } \\
\hline \multirow[t]{4}{*}{ UAN } & S-100\% & 13.86 & 0.28 & 2.31 & 0.13 & 0.15 \\
\hline & $\mathrm{S}-75 \%+\mathrm{F}$ & 12.62 & 0.30 & 2.46 & 0.15 & 0.17 \\
\hline & L-75\% & 13.81 & 0.30 & 2.51 & 0.14 & 0.16 \\
\hline & $\mathrm{L}-75 \%+\mathrm{F}$ & 13.42 & 0.28 & 2.24 & 0.15 & 0.17 \\
\hline \multirow[t]{4}{*}{ ENTEC 26} & S-100\% & 14.14 & 0.32 & 2.47 & 0.13 & 0.15 \\
\hline & $\mathrm{S}-75 \%+\mathrm{F}$ & 13.52 & 0.28 & 2.11 & 0.12 & 0.15 \\
\hline & $\mathrm{L}-75 \%$ & 13.99 & 0.31 & 2.35 & 0.14 & 0.13 \\
\hline & $\mathrm{L}-75 \%+\mathrm{F}$ & 13.21 & 0.35 & 2.63 & 0.16 & 0.16 \\
\hline \multirow{3}{*}{$\begin{array}{l}\text { Mean for: } \\
\text { fertilizer }\end{array}$} & & & & & & \\
\hline & UAN & 13.43 & 0.29 & 2.38 & 0.14 & 0.16 \\
\hline & ENTEC 26 & 13.71 & 0.32 & 2.39 & 0.14 & 0.15 \\
\hline \multirow{4}{*}{$\begin{array}{r}\text { fertilization } \\
\text { method }\end{array}$} & S-100\% & 14.00 & 0.30 & 2.39 & 0.13 & 0.15 \\
\hline & $\mathrm{S}-75 \%+\mathrm{F}$ & 13.07 & 0.29 & 2.29 & 0.14 & 0.16 \\
\hline & L-75\% & 13.90 & 0.31 & 2.43 & 0.14 & 0.15 \\
\hline & $\mathrm{L}-75 \%+\mathrm{F}$ & 13.31 & 0.31 & 2.43 & 0.16 & 0.16 \\
\hline \multirow{3}{*}{$\begin{array}{l}\mathrm{LSD}_{0.05} \text { for: } \\
\\
\text { fertili }\end{array}$} & fertilizer & n.s. & 0.012 & n.s. & n.s. & n.s. \\
\hline & zation method & n.s. & n.s. & n.s. & 0.013 & n.s. \\
\hline & interaction & n.s. & 0.024 & n.s. & 0.019 & n.s. \\
\hline
\end{tabular}

Note: see Table 1

Table 3. Effects of nitrogen fertilizer and fertilization method on the contents of nitrogen, sugars and phenols in red beet roots in 2006

\begin{tabular}{|c|c|c|c|c|c|c|}
\hline Fertilizers & $\begin{array}{l}\text { Fertilization } \\
\text { method }\end{array}$ & $\begin{array}{l}\mathrm{NH}_{4}^{+} \\
\mathrm{mg} \cdot \mathrm{kg}^{-1} \\
\text { f.m. }\end{array}$ & $\begin{array}{l}\mathrm{NO}_{3}^{-} \\
\mathrm{mg} \cdot \mathrm{kg}^{-1} \\
\text { f.m. }\end{array}$ & $\begin{array}{l}\text { N protein } \\
\% \text { d.m. }\end{array}$ & $\begin{array}{l}\text { Sugars } \\
\% \text { f.m. }\end{array}$ & $\begin{array}{l}\text { Phenols } \\
\mathrm{mg} \cdot 100 \mathrm{~g}^{-1} \\
\text { f.m. }\end{array}$ \\
\hline \multirow[t]{4}{*}{ UAN } & S-100\% & 347 & 384 & 1.55 & 5.35 & 186 \\
\hline & $\mathrm{S}-75 \%+\mathrm{F}$ & 348 & 200 & 1.81 & 6.01 & 190 \\
\hline & $\mathrm{L}-75 \%$ & 340 & 186 & 1.75 & 5.75 & 197 \\
\hline & $\mathrm{L}-75 \%+\mathrm{F}$ & 344 & 289 & 1.97 & 6.30 & 173 \\
\hline \multirow[t]{4}{*}{ ENTEC 26} & S-100\% & 346 & 230 & 1.73 & 5.97 & 188 \\
\hline & $\mathrm{S}-75 \%+\mathrm{F}$ & 346 & 288 & 1.67 & 5.78 & 187 \\
\hline & L-75\% & 299 & 100 & 2.16 & 6.45 & 187 \\
\hline & $\mathrm{L}-75 \%+\mathrm{F}$ & 339 & 320 & 1.67 & 5.67 & 178 \\
\hline \multirow{3}{*}{$\begin{array}{l}\text { Means for: } \\
\text { fertilizers }\end{array}$} & & & & & & \\
\hline & UAN & 344 & 265 & 1.77 & 5.85 & 186 \\
\hline & ENTEC 26 & 332 & 234 & 1.81 & 5.96 & 185 \\
\hline \multirow{4}{*}{$\begin{array}{r}\text { fertilization } \\
\text { method }\end{array}$} & S- $100 \%$ & 346 & 307 & 1.64 & 5.66 & 187 \\
\hline & $\mathrm{S}-75 \%+\mathrm{F}$ & 347 & 244 & 1.74 & 5.90 & 188 \\
\hline & $\mathrm{L}-75 \%$ & 320 & 143 & 1.96 & 6.10 & 192 \\
\hline & $\mathrm{L}-75 \%+\mathrm{F}$ & 341 & 305 & 1.82 & 5.99 & 176 \\
\hline \multirow{3}{*}{\multicolumn{2}{|c|}{$\begin{array}{rr}\mathrm{LSD}_{0.05} \text { for: } & \text { fertilizer } \\
\text { fertilization method } \\
\\
\text { interaction }\end{array}$}} & n.s. & n.s. & n.s. & n.s. & n.s. \\
\hline & & n.s. & 116.6 & 0.099 & 0.184 & n.s. \\
\hline & & n.s. & n.s. & 0.139 & 0.261 & n.s. \\
\hline
\end{tabular}

Note: see Table 1 
Table 4. Effects of nitrogen fertilizer and fertilization method on the contents of dry matter, phosphorus, potassium, magnesium and calcium in red beet roots in 2006

\begin{tabular}{|c|c|c|c|c|c|c|}
\hline \multirow{2}{*}{ Fertilizer } & \multirow{2}{*}{$\begin{array}{c}\text { Fertilization } \\
\text { method }\end{array}$} & \multirow{2}{*}{$\begin{array}{c}\text { Dry matter } \\
\%\end{array}$} & $P$ & $\mathrm{~K}$ & $\mathrm{Mg}$ & $\mathrm{Ca}$ \\
\hline & & & \multicolumn{4}{|c|}{ \%d.m. } \\
\hline \multirow[t]{4}{*}{ UAN } & S-100\% & 13.30 & 0.44 & 3.27 & 0.19 & 0.20 \\
\hline & $\mathrm{S}-75 \%+\mathrm{F}$ & 13.68 & 0.38 & 3.14 & 0.21 & 0.24 \\
\hline & L-75\% & 14.16 & 0.40 & 3.04 & 0.18 & 0.17 \\
\hline & $\mathrm{L}-75 \%+\mathrm{F}$ & 13.77 & 0.46 & 2.94 & 0.18 & 0.18 \\
\hline \multirow[t]{4}{*}{ ENTEC 26} & S-100\% & 14.28 & 0.45 & 2.82 & 0.19 & 0.20 \\
\hline & $\mathrm{S}-75 \%+\mathrm{F}$ & 14.13 & 0.33 & 2.97 & 0.19 & 0.18 \\
\hline & L-75\% & 14.19 & 0.34 & 2.67 & 0.18 & 0.19 \\
\hline & $\mathrm{L}-75 \%+\mathrm{F}$ & 13.06 & 0.34 & 3.33 & 0.20 & 0.20 \\
\hline \multirow{3}{*}{$\begin{array}{l}\text { Mean for: } \\
\text { fertilizer }\end{array}$} & & & & & & \\
\hline & UAN & 13.73 & 0.42 & 3.10 & 0.19 & 0.20 \\
\hline & ENTEC 26 & 13.91 & 0.36 & 2.95 & 0.19 & 0.19 \\
\hline \multirow{4}{*}{$\begin{array}{r}\text { fertilization } \\
\text { method }\end{array}$} & S-100\% & 13.79 & 0.44 & 3.04 & 0.19 & 0.20 \\
\hline & $\mathrm{S}-75 \%+\mathrm{F}$ & 13.90 & 0.35 & 3.06 & 0.20 & 0.21 \\
\hline & $\mathrm{L}-75 \%$ & 14.18 & 0.37 & 2.86 & 0.18 & 0.18 \\
\hline & $\mathrm{L}-75 \%+\mathrm{F}$ & 13.42 & 0.40 & 3.13 & 0.19 & 0.19 \\
\hline \multirow{3}{*}{$\begin{array}{l}\mathrm{LSD}_{0.05} \text { for: } \\
\text { fertili }\end{array}$} & fertilizer & n.s. & 0.025 & 0.125 & n.s. & $\mathrm{n} . \mathrm{s}$ \\
\hline & zation method & n.s. & 0.036 & 0.177 & 0.014 & 0.021 \\
\hline & interaction & n.s. & 0.051 & 0.250 & 0.020 & 0.029 \\
\hline
\end{tabular}

Note: see Table 1

It is worth to notice that there was a significant interaction between type of fertilizer and method of application on $\mathrm{NO}_{3}{ }^{-}$content in 2005 (Table 1). The detailed analysis shows that the lowest $\mathrm{NO}_{3}{ }^{-}$content in UAN beets was found for S-100\% method, whereas in ENTEC 26 beets there were no differences between S-100\%, S-75\%+F and L-75\% methods, being significantly lower than the nitrate content in $\mathrm{L}-75 \%+\mathrm{F}$ beets. There were also significant interactions between type of fertilizer and method of application on the contents of sugars (in both years), $\mathrm{N}$-protein (in 2006) and on all minerals studied except $\mathrm{Ca}$ (in 2005).

It should be noticed that in the year 2006 the plants accumulated 2.5 -fold more nitrates, about 0.5 -fold more phenols, and more minerals than in 2005. On the other hand, the plants accumulated about $20 \%$ more $\mathrm{NH}_{4}{ }^{+}$and sugars in 2005 .

\section{DISCUSSION}

Biological value of red beets depends from one side on the high contents of protein, sugars and phenols and from the other side on a low content of nitrates. Thus lowering of the nitrate content would be beneficial for human nutrition. The results of the present study show that this approach can be achieved by using ENTEC 26, the nitrogen fertilizer which contains ammonium nitrogen form and nitrification inhibitor DMPP. Hähndel et al. (1994) observed a similar decrease in nitrate ion concentration in red cabbage and celery plants at the application of ammonium form of nitrogen and nitrification inhibitor (DCD). 
On the other hand, a type of nitrogen fertilizer in a present study had no effect on other nutritionally beneficial compounds such as protein, sugars or phenols.

The effect of a second experimental factor, method of nitrogen fertilization, on nitrate content was not so obvious. The localized nitrogen application by CULTAN method lowered nitrate content only in 2006, similarly as it was shown by Sommer (1991). The reason is not clear why in 2006 year the beets fertilized superficially (S-100\%) contained the highest amount of nitrates, since in 2005 this method gave the lowest results. Irrespective of the fertilizer type, the nitrate content was almost 2.5 times higher in 2006 than in 2005. This tendency might have been resulted from lower mean air temperature in 2005, particularly at the period of an intensive root growth when the air temperature in 2005 was about $5^{\circ} \mathrm{C}$ lower than in 2006 (Fig. 1). Higher air temperatures in 2006 might accelerate ammonification and nitrification processes in the soil, which might increase the supply of nitrate ions and their uptake by plants. The differences between years in nitrate content in beet roots might also be connected with a prolonged plant vegetation period in 2005 . The plants may have used the absorbed nitrogen to a greater extent.

The effect of foliar nitrogen application was also not univocal. In 2006, irrespective of the fertilizer used, additional foliar nutrition increased nitrate content in plants fertilized by localized method (L-75\%+F vs. L-75\%). Such tendencies were not seen in 2005. Replacing of some part of nitrogen supplied superficially by foliar application (S-100\%vs. S- $75 \%+\mathrm{F})$ gave opposite results in 2005 and 2006. Similarly to present study, the effect of foliar nitrogen nutrition on nitrate contents has also been controversial in other studies. A decrease in nitrate content was observed in lettuce, carrots and pumpkins (Mareczek et al. 2000, Rożek et al. 2000, Biesiada 2005), whereas Kowalska et al. (2006) found no effects in lettuce and Smoleń et al. (2006) in carrots. Based on the results of a present study neither CULTAN method nor foliar nitrogen nutrition are effective means of reducing nitrate content in the red beets.

Beets fertilized with different methods contained the same levels of dry matter, $\mathrm{NH}_{4}$ and phenols. A lack of effect of localized fertilization on dry matter content is in opposition to the results of Sommer (2001), who found 10-15\% increase in dry matter content of plants fertilized by CULTAN method. Such plants formed smaller cells, with thicker cell walls.

Soluble sugar and N-protein concentrations in beets differed between years. Although differences in sugar concentration among fertilization method within each year were statistically significant, and although in both years the highest sugar contents were found in L-75\% beets, it seems that the differences among fertilization methods were only numerical and have no practical meaning for biological value of red beets. The differences among fertilization methods in N-protein content were also without practical meaning for biological value.

Except for $\mathrm{Mg}$, fertilization method had no effect on mineral composition of red beets in 2005. On the other hand, although differences between fertilization method on mineral composition of beets harvested in 2006 were signifi- 
cant, they seem also not to have practical meaning. According to Sommer (2001) localized fertilization with a reduced form of nitrogen (CULTAN method) allows to avoid competition between $\mathrm{K}^{+}$and $\mathrm{Ca}^{+2}$ uptake, which may occur when plants are fertilized with ammonium form of nitrogen. Therefore, the CULTAN method may prevent a reduction in $\mathrm{K}^{+}$and $\mathrm{Ca}^{2+}$ uptake by plants. The results of a present study do not confirm it since the beets fertilized by this method, either alone (L-75\%) or with foliar supplementation $(\mathrm{L}-75 \%+\mathrm{F})$ do not contain more $\mathrm{K}$ and $\mathrm{Ca}$ than those fertilized by other methods in 2005 year. As a matter of fact localized fertilization (L-75\%) significantly lowered $\mathrm{K}$ and $\mathrm{Ca}$ contents in beets in 2006 and the reason for such effect is unclear.

\section{CONCLUSIONS}

It can be concluded that from two studied factors, a type of nitrogen fertilizer had more pronounced effect than fertilization method on biological value of red beets roots. Fertilization with ammonium nitrogen form and nitrification inhibitor DMPP (ENTEC 26) may be an effective tool in reducing the nitrate content in red beets. The effect of fertilization method on the biological value of red beets roots depended very much on the year of cultivation.

\section{REFERENCES}

Biesiada A. 2005. Wpływ dokarmiania dolistnego mocznikiem i siarczanem amonu na zawartość azotanów w sałacie. Zesz. Nauk. AR we Wrocławiu, Rolnictwo LXXXVI 515: 47-52. [in Polish]

Chaves B., Opoku A., De Neve S., Boecks P., Van Cleemput O., Hofman G. 2006. Influence of DCD and DMPP on soil N dynamics after incorporation of vegetable crop residues. Biol. Fert. Soils 43: 62-68.

Hähndel R., Lang H., Hermann P. 1994. Wirkung von Ammonium-stabilisierten Düngern auf Ertrag und Qualität von Gemüse. Agrobiol. Res. 47,2: 101-108. [in German].

Jędrzejczak R. 1991. Oznaczenie zawartości, arsenu, ołowiu, miedzi, cynku i cyny w kompotach, przecierach i dżemach, metodą absorpcyjnej spektrometrii atomowej /AAS/. Prace Instytutów i Lab. Bad. Przem. Spoż. 43: 31-41 [in Polish]

Kowalska I., Sady W., Szura A. 2006. [Effects of nitrogen form, foliar nutrition and growing place on yield and quality of lettuce.] Acta Agroph. 7: 619-631. [in Polish with English summary]

Mareczek A., Rożek S., Sady W. 2000. Wpływ pozakorzeniowego dokarmiania roślin na wielkość i jakość plonu dyni. Zesz. Nauk. AR w Krakowie 364: 131-134. [in Polish]

Peri C., Pompei G. 1971. An assay of different phenolic fraction in wines. J. Amer. Enol. Vitic. 22: 55.

Rożek S. 2000. Czynniki wpływające na akumulację azotanów w plonie warzyw. Zesz. Nauk. AR w Krakowie, ser. Sesja Naukowa 71: 19-31. [in Polish]

Rożek S., Sady W., Kasprzyk A. 2000. Wpływ pozakorzeniowego dokarmiania roślin na wielkość i jakość plonu marchwi. Zesz. Nauk. AR w Krakowie 364: 159-162. [in Polish] 
Smoczyński S.S., Skibniewska K.A. 1996. Azotany jako higieniczny problem jakości żywności. Zesz. Probl. Post. Nauk Roln. 440: 361-364. [in Polish]

Smoleń S., Wojciechowska R., Sady W., Szura A. 2006. [Effect of fertilization with different form of nitrogen and foliar nutrition on yield and nitrogen metabolism in carrot roots (Daucus carota L.).] Acta Agroph. 7: 721-732. [in Polish with English summary]

Sommer K. 1991. Ammonium-Depotdüngung Grundlagen. Stand der Entwicklung, Perspektiven. Forschungberichte 1: 6-41. [in German]

Sommer K. 2001. Grundlagen des „CULTAN”-Verfahrens. In: Landbauforschung Völkenrode, Anbauverfahren mit N-Injektion (CULTAN) Ergebnisse, Perspektiven, Sonderheft 245: 1-22. [in German]

Yemm E.W., Wills A.J. 1954. The estimation of carbohydrates in plant extracts by antrone. Bioch. J. 57: 508-514.

\section{WARTOŚĆ BIOLOGICZNA BURAKA ĆWIKŁOWEGO W ZALEŻNOŚCI OD NAWOŻENIA AZOTOWEGO}

W latach 2005 i 2006 w doświadczeniu wazonowym badano wpływ rodzaju nawozu azotowego oraz sposobu nawożenia na wartość biologiczną korzeni buraka ćwikłowego odm. Boro $F_{1}$. Nawożenie azotowe przedsiewne przeprowadzono $z$ wykorzystaniem nawozów azotowych RSM - Roztwór Saletrzano Mocznikowy lub ENTEC 26 (nawóz zawierający inhibitor nitryfikacji). Nawożenie azotowe wykonano w następujący sposób: przedsiewnie-powierzchniowo w dawce $90 \mathrm{~kg} \mathrm{~N} \cdot \mathrm{ha}^{-1}(\mathrm{~S}-100 \%)$; przedsiewnie-powierzchniowo $\mathrm{w}$ dawce $67,5 \mathrm{~kg} \mathrm{~N} \cdot \mathrm{ha}^{-1}$ i pozakorzeniowo $\mathrm{w}$ trakcie wegetacji roślin $(\mathrm{S}-75 \%+\mathrm{F})$; przedsiewnie-zlokalizowane $\mathrm{w}$ dawce $67,5 \mathrm{~kg} \mathrm{~N} \cdot \mathrm{ha}^{-1}$ (L-75\%); przedsiewnie-zlokalizowane $\mathrm{w}$ dawce $67,5 \mathrm{~kg} \mathrm{~N} \cdot \mathrm{ha}^{-1}$ i pozakorzeniowo $\mathrm{w}$ trakcie wegetacji roślin $(\mathrm{L}-75 \%+\mathrm{F})$. W uzyskanym materiale roślinnym oznaczano zawartość suchej masy, cukrów, fenoli, $\mathrm{NO}_{3}^{-}, \mathrm{NH}_{4}^{+}$, N-białkowy oraz $\mathrm{P}, \mathrm{K}, \mathrm{Mg}, \mathrm{Ca}$.

Rodzaj nawozu azotowego nie miał wpływu na zawartość suchej masy, $\mathrm{NH}_{4}^{+}$, N-białkowego, cukrów, fenoli, Ca i Mg w obydwu latach uprawy oraz na zawartość K w 2005 roku. Nawożenie roślin nawozem ENTEC 26 wpłynęło na uzyskanie roślin o niższej zawartości azotanów, co było szczególnie widoczne w 2005 roku. Wpływ sposobu nawożenia na zawartość azotanów był niejednoznaczny. W 2005 roku najniższą zawartością azotanów charakteryzowały się korzenie roślin nawożonych przedsiewniepowierzchniowo S-100\%, natomiast w roku 2006 przedsiewnie-zlokalizowane L-75\%. W obydwu latach uprawy najwięcej cukrów zawierały korzenie roślin nawożonych przedsiewnie-zlokalizowane L-75\%, natomiast najmniej N-białkowego rośliny nawożone przedsiewnie-powierzchniowo S-100\%. Sposób nawożenia nie miał wpływu na zawartość suchej masy, $\mathrm{NH}_{4}^{+}$i fenoli (rok 2005 i 2006). Zawartość składników mineralnych (P, K, $\mathrm{Ca}, \mathrm{Mg}$ ) w korzeniach jedynie w 2006 roku zależała od sposobu nawożenia.

Wydaje się, że obniżenie zawartości azotanów w buraku ćwikłowym można uzyskać poprzez stosowanie nawozów azotowych zawierających inhibitor nitryfikacji. Nie obserwowano jednoznacznego i powtarzalnego wpływu sposobu stosowania nawozu na wartość odżywczą buraka, jednak stwierdzono różnice w porównywanych latach badań. 